\title{
Karakteristik Termal Rumah Suku Dayak di Kalimantan Tengah (Studi Kasus: Rumah Betang Buntoi, Rumah Betang Toyoi, dan Rumah Betang di TMII)
}

\author{
Dona Jhonnata $^{1 *}$, Nugroho Ifadianto ${ }^{1}$, Dini Hardilla ${ }^{1}$ \\ ${ }^{1}$ Perancangan Arsitektur, Prodi S1 Arsitektur, Fakultas Teknik Jurusan Arsitektur, Universitas Lampung \\ *Penulis Korespondensi: dona.jhonnata@eng.unila.ac.id
}

\begin{abstract}
Abstrak:
Tujuan Penelitian mengetahui nilai suhu yang dihasilkan pada bangunan rumah Suku Dayak di Kalimantan Tengah dan yang ada di Jakarta. Kesimpulan apakah dengan karakteristik termal yang dimiliki pada rumah Suku Dayak di Kalimantan Tengah dapat mengatasi kondisi suhu luar iklim tropis di Kalimantan yang memiliki kelembaban dan suhu udara relatif tinggi serta pengaruh radiasi matahari yang tinggi. Yang dimaksud karakteristik adalah sifat khusus, ataupun ciri utama bangunan yang terkait dengan termal, pengumpulan data dilakukan dengan metode pendekatan Kuantitatif untuk menguji teori kenyamanan termal yang telah ada (pengukuran di dasari atas angka). Standar hasil riset dibandingkan dengan kondisi lingkungannya untuk investigasi hubungan apakah bangunan yang terbentuk dapat mengatasi kondisi ruang luar pada bangunannya. Hasil penelitian maupun temuan yang didapatkan bahwa rumah Betang Toyoi ternyata lebih mampu mengatasi keadaan suhu ruang luar yang tinggi, dibandingkan dengan Rumah Betang lainnya.
\end{abstract}

Kata Kunci: Tujuan; Kesimpulan; Termal; Kenyamanan; Karakteristik; Kuantitatif

\section{Latar Belakang}

Ketidaknyamanan termal pada bangunan tradisional dapat terjadi karena berbagai aspek, salah satunya karena desain yang terbentuk akibat dari pengaruh budaya khas masyarakatnya sebagai peran identitas kebudayaan. Di iklim tropis lembab pada umumnya bangunan-bangunan didesain dengan sistem penghawaan alami yang memaksimalkan kualitas suhu dan kelembaban yang baik untuk dapat mendinginkan struktur bangunan ataupun pencapaian kenyamanan fisiologis (Swasti, 2016). Kenyamanan fisiologis dapat dicapai dengan kenyamanan termal sebagai contoh saat pembuatannya yang berpedoman agar desain memiliki kesesuaian, keseimbangan, tidak merusak alam. Pedoman ini secara tidak langsung berpengaruh pada temperatur bangunan baik dari dalam maupun luar, dimana faktor karakteristik termal sering diabaikan dalam usaha konservasi atau pembuatan kembali bangunan tradisional pada area perkotaan saat ini. Ada banyak studi tentang berbagai cara untuk mengevaluasi kenyamanan termal untuk mengetahui apakah lingkungan termal cocok untuk hidup nyaman (Santoso, 2012).

Hubungan simbiosis yang erat dengan alam sekitarnya dari generasi ke generasi ini pada akhirnya melahirkan kearifan dan teknologi tradisional tersendiri yang unik dan spesifik yang tidak terduplikasi dan diketemukan di tempat lain (Samsoedin et al., 2010). Dan teknologi tersebut perlu untuk dilestarikan agar makna kultural pada bangunan konservasi dapat dirasakan oleh masyarakat pendahulunya. Hal ini perlu diperhatikan karena rumah Suku Dayak dibangun saat ini tidak memperhatikan faktor kenyamanan termal, dan hal tersebut terlihat dari penyelesaian mengatasi masalah, misalnya dengan menggunakan alat air conditioner. Implementasi pengkondisian udara pada bangunan baru dapat menyebabkan kesan arsitektur terasa lebih dominan eklektisme dan tidak lagi unik, salah satu kajian yang dapat dilakukan misalnya dengan kuantifikasi bangunan. Kuantifikasi berdasarkan rasa kenyamanan termal dilakukan berdasarkan hasil penelitian empiris terhadap sejumlah variabel klimatik meliputi suhu udara, suhu radiatif, kelembaban udara, dan kecepatan angin (Toding et al., 2015).

Apabila ditelaah kembali pada masa lalu masyarakat Suku Dayak ternyata hidup secara berkelompok, mereka menjunjung tinggi adat yang diwariskan pendahulunya. Di kalangan Dayak itu sendiri terdapat keragaman yang besar antara Suku yang satu dengan yang lainnya dari sudut Bahasa, kesenian, upacara-upacara, arsitektur rumah, dan lainnya (Singarimbun, 1991). Hal ini diterapkan pada rumah mereka yang disebut rumah Betang, dan rumah ini memiliki konsep persatuan didalam setiap keluarga yang harus terwujud agar dapat bertahan dari serangan musuh. Bentuk rumah yang sederhana tanpa memiliki bukaan atau ventilasi berupa jendela, rumah disampingnya sebagai rumah tinggal juga digunakan sebagai tempat acara-acara yang bersifat adat, ritual, dan sebagainya (Wahyudi, 2018). Tujuan tersebut menyebabkan ruang keluarga dibuat begitu besar agar memenuhi banyaknya anggota keluarga, walaupun pada perjalanan waktu terdapat beberapa perubahan seperti penempatan jendela akibat berkurangnya konflik antar Suku yang terjadi. 
Rumah Panjang atau Lamin memiliki konstruksi rumah panggung dengan bentukan memanjang dan digunakan sebagai tempat tinggal 8 hingga 10 keluarga (Putri, 2017). Karena sifatnya itu Rumah Panjang memiliki akses berupa tangga kecil, dilakukan agar musuh memiliki jalur terbatas ketika musuh berupaya masuk, disamping tangga kecil yang juga dapat ditarik dari atas oleh penghuni bangunan. Konstruksi bangunan terdiri dari material kayu, untuk Betang Toyoi dindingnya menggunakan kulit pohon kayu dengan celah-celah kecil pada setiap rongga kulit pohon tersebut. Memiliki juga jendela intip pada bagian tawing (gunungan atap) yang dulunya berfungsi sebagai tempat mengintip keadaan diluar (Usop, 2019). Pada lantainya juga memiliki celah kecil pada setiap rongga papan agar udara dapat masuk ke dalam, dan tentunya dari karakteristik fisik yang dijabarkan memiliki kaitan terhadap kenyamanan termal yang terjadi baik secara langsung maupun tidak.

Pengaruh budaya lainnya yang diterapkan dalam konsep arsitektur rumah Suku Dayak terkait dari karakteristik termal salah satunya adalah permasalahan orientasi, dan rumah Suku Dayak umumnya mengutamakan orientasi pada arah sungai. Permukiman tradisional masyarakat Indonesia ditinjau dari segi historis banyak berada di daerah aliran sungai karena akses transportasi (Hamidah \& Garib, 2014). Selain hal tersebut sungai juga merupakan sumber penghidupan dan pada studi kasus terpilih ternyata menghadap juga ke arah Timur, sedangkan diketahui rumah Suku Dayak berbentuk memanjang dengan bidang panjangnya berorientasi langsung pada arah timur dan arah belakangnya yang menghadap barat. Diketahui untuk orientasi bangunan dan perlindungan terhadap cahaya matahari, berlaku aturan-aturan dasar seperti bahwa sebaiknya fasade terbuka menghadap selatan atau utara, agar meniadakan radiasi langsung dari cahaya matahari rendah dan konsentrasi tertentu yang menimbulkan pertambahan panas (Lippsmeier, 1994). Proses penyegaran udara secara alamiah, penggunaan cross ventilation memindahkan udara panas yang diakibatkan sinar matahari keluar (Usop, 2015) ikut mempengaruhi karakteristik termal yang terjadi.

Kondisi rumah Suku Dayak yang menjaga keselarasan antara kehidupan dengan lingkungan membentuk hirarki tersendiri dengan bentuk bangunan yang bersifat panggung. Material, bentuk atap, elemen bangunan, dibuat berdasarkan aturan yang saling berkaitan dan memiliki pengaruh terhadap karakteristik termal. Produktifitas manusia cenderung menurun atau rendah pada kondisi udara yang tidak nyaman seperti halnya terlalu dingin atau terlalu panas (Karyono, 2010). Persoalan tingginya temperatur udara di dalam bangunan dibandingkan dengan temperatur luar tidak saja disebabkan oleh posisi bukaan atau kaca langsung ke arah matahari, namun juga dapat terjadi karena kurangnya ventilasi silang didalam bangunan, atau karena pelepasan kalor dari dinding dan atap secara radiasi ke dalam bangunan, tanpa ada bidang atau elemen bangunan lain yang menahannya (Karyono, 2016). Dari beberapa hal tersebut diketahui bahwa kajian karakteristik termal cukup penting dilakukan, disamping manfaat konservasi juga sebagai khasanah literatur khususnya bidang pariwisata di Kalimantan Tengah.

Penelitian serupa sebelumnya juga pernah dilakukan terkait dengan kenyamanan termal, dan peneliti sebelumnya mengatasi permasalahan panas adalah dengan mendalami aspek pengaruh bentukan arsitektur. Pada penelitian ini memiliki perbedaan dalam mencari karakteristik termal tidak hanya terkait dengan bentukan, tetapi juga pengaruh perbandingan dengan objek lainnya yang diketahui memiliki bentuk, site, serta lokasi berbeda. Kemudian ada pula penelitian kenyamanan termal lain dengan kajian lengkap, seperti penggunaan data temperatur kering, temperatur basah, temperatur efektif, kelembaban, kecepatan angin. Namun kekurangan dari penelitian ini adalah metode yang mengeneralkan seluruh ruangan dengan satu angka pengukuran, dan atas dasar tersebut penulis berusaha untuk menutupi kekurangan dengan menghitung setiap ruangan berbeda pada setiap objek studi, hal ini tentunya diyakini memiliki pengaruh dalam mencari kesimpulan akhir yang dapat menambah wawasan bidang arsitektur.

\section{Metode}

Kenyamanan termal bersifat spesifik, yaitu terkait suhu dan kelembaban, maka metode yang digunakan adalah pendekatan kuantitatif. Metode ini sebagai metode ilmiah / scientific karena telah memenuhi kaidah-kaidah ilmiah yaitu konkrit / empiris, obyektif, terukur, rasional, dan sistematis (Sugiyono, 2019). Pendekatan ini akan dapat menguji teori kenyamanan termal berdasarkan angka, menggambarkan secara sistematis, faktual, alamiah, mengenai fakta dilapangan, termasuk sifat dan hubungan antar gejala khususnya yang berkaitan dengan suhu. Penentuan objek studi kasus adalah pada rumah tradisional Suku Dayak di Kalimantan Tengah yang masih berdiri, salah satunya seperti rumah Betang Buntoi, Betang Toyoi, dan Rumah Betang Provinsi Kalimantan Tengah di TMII Jakarta. Rumah Betang TMII dipilih sebagai pembanding dimana peneliti secara khusus mendetail, memilih, dan mengkaji karakteristik termal yang terjadi dengan perbedaan daerah aslinya pada area perkotaan.

Metode ini mensyaratkan banyak batasan seperti misalnya latar alamiah, yaitu penelitian didasarkan konteks dari suatu keutuhan (entity) seperti kaitan posisi bangunan, angin, iklim, vegetasi, dan hal-hal yang berkaitan mengenai kenyamanan termal. Manusia dan pengukuran kelembaban diposisikan sebagai alat (instrument), dan peneliti terlibat langsung di lapangan (participant observation). Analisis data secara induktif, dan data yang di kumpulkan bukan berupa kata-kata tetapi berupa angka-angka, selain itu pertanyaan mengapa, alasan apa, dan bagaimana, berapa, senantiasa dimanfaatkan oleh peneliti. Metode ini lebih mementingkan hasil (berupa angka), namun tetap proses juga perlu diperhitungkan. Batasan lainnya ditentukan oleh fokus, fokus hanya pada hal yang berkaitan 
dengan kenyamanan termal dengan adanya parameter yang jelas.

\subsection{Metode Pengumpulan Data}

Instrumen penelitian menggunakan alat tertentu agar mendapatkan data yang diharapkan serta dapat dikaji untuk disimpulkan.
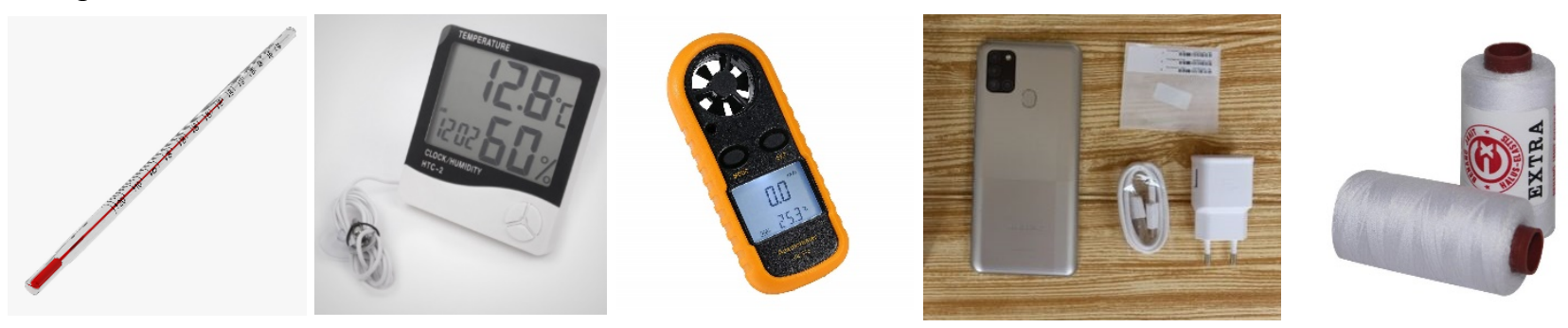

Gambar 1. Ilustrasi alat, dari kiri ke kanan Termometer Tabung untuk ruangan, Termometer \& Hygrometer Digital, Anemometer tipe GM816, Handphone Samsung Tipe A21, dan Benang Jahit

Tabel 1. Spesifikasi Alat yang digunakan untuk pengumpulan data (Sumber: Observasi Lapangan, 2020)

\begin{tabular}{|c|c|c|c|c|}
\hline Nama Alat & Spesifikasi Alat & Elevasi & $\begin{array}{c}\text { Lama } \\
\text { Pengukuran }\end{array}$ & $\begin{array}{l}\text { Pencatatan } \\
\text { Durasi }\end{array}$ \\
\hline Termometer. & $\begin{array}{l}\text { Termometer yang dipilih adalah } \\
\text { Termometer untuk menghitung } \\
\text { suhu ruangan, Termometer ini } \\
\text { berbentuk tabung dan memiliki } \\
\text { kualifikasi untuk menghitung } \\
\text { suhu ruangan. Penggunaannya } \\
\text { dilengkapi alat pendukung lain } \\
\text { yaitu dengan Benang Jahit, dan } \\
\text { disebar pada setiap ruangan } \\
\text { (jumlah total sekitar } 17 \text { alat) } \\
\text { yang dirasa dapat mewakili nilai } \\
\text { pengukuran baik suhu dalam } \\
\text { maupun luar. }\end{array}$ & $\begin{array}{l}\text { Benang Jahit } \\
\text { digunakan untuk } \\
\text { mengikat termo- } \\
\text { meter agar "mela- } \\
\text { yang" serta tidak } \\
\text { terpengaruh oleh } \\
\text { benda - benda lain } \\
\text { disekitarnya yang } \\
\text { menghantarkan } \\
\text { energi panas atau } \\
\text { dingin, elevasi yang } \\
\text { dipilih adalah } \\
\text { elevasi yang dirasa } \\
\text {-kan manusia } \\
\text { ketika menempati } \\
\text { bangunan tersebut } \\
( \pm 1.2 \text { meter). }\end{array}$ & $\begin{array}{l}\text { Lama } \\
\text { pengukuran } \\
\text { bervariasi } \\
\text { karena ada } \\
2 \text { kali peng- } \\
\text { ukuran } \\
\text { pada setiap } \\
\text { objek, } \\
\text { dalam hal } \\
\text { ini dari } \\
\text { Pukul 07.00 } \\
\text { WIB - } \\
\text { 17.00 WIB. }\end{array}$ & $\begin{array}{l}\text { Pencatatan durasi } \\
\text { dilakukan setiap } \\
1 \text { jam dan setiap } \\
30 \text { menit. }\end{array}$ \\
\hline $\begin{array}{l}\text { Termometer \& } \quad \text { Hygrometer Digital. } \\
\text { Hyol }\end{array}$ & $\begin{array}{l}\text { Alat pengukur suhu dan } \\
\text { kelembaban secara digital, } \\
\text { tipenya ialah HTC }-2 \text {. Karena } \\
\text { alat ini cukup mahal maka } \\
\text { jumlahnya tidak banyak, yaitu } \\
\text { hanya 3unit saja. }\end{array}$ & $\begin{array}{l}\text { Elevasi yang di } \\
\text { pilih adalah elevasi } \\
\text { yang dirasakan } \\
\text { manusia ketika } \\
\text { menempati } \\
\text { bangunan tersebut } \\
( \pm 1.2 \text { meter). }\end{array}$ & $\begin{array}{l}\text { Lama } \\
\text { pengukuran } \\
\text { bervariasi } \\
\text { karena ada } \\
2 \text { kali peng- } \\
\text { ukuran pada } \\
\text { setiap } \\
\text { objek, } \\
\text { dalam hal } \\
\text { ini dari } \\
\text { Pukul } 07.00 \\
\text { WIB - } \\
\text { 17.00 WIB. }\end{array}$ & $\begin{array}{l}\text { Pencatatan durasi } \\
\text { dilakukan setiap } \\
1 \text { jam. }\end{array}$ \\
\hline Anemometer. & $\begin{array}{l}\text { Alat pengukur kecepatan angin } \\
\text { dan temperatur secara digital, } \\
\text { tipenya GM816. Karena alat ini } \\
\text { cukup mahal maka } \\
\text { penggunaannya dibawa ber- } \\
\text { pindah-pindah juga antara ruang } \\
\text { satu dengan lainnya. }\end{array}$ & $\begin{array}{l}\text { Elevasi alat } \\
\text { anemometer dise- } \\
\text { suaikan dengan } \\
\text { tinggi jendela, dan } \\
\text { berdekatan dengan } \\
\text { bukaan jendela. }\end{array}$ & $\begin{array}{l}\text { Lama } \\
\text { pengukuran } \\
\text { adalah dari } \\
\text { pukul } 07.00 \\
\text { WIB - } \\
17.00 \text { WIB. }\end{array}$ & $\begin{array}{l}\text { Pencatatan durasi } \\
\text { dilakukan setiap } \\
1 \text { jam. }\end{array}$ \\
\hline
\end{tabular}




\begin{tabular}{|c|c|c|c|c|}
\hline Nama Alat & Spesifikasi Alat & Elevasi & $\begin{array}{c}\text { Lama } \\
\text { Pengukuran }\end{array}$ & $\begin{array}{l}\text { Pencatatan } \\
\text { Durasi }\end{array}$ \\
\hline $\begin{array}{l}\text { Recorder \& } \\
\text { Dokumentasi foto. }\end{array}$ & $\begin{array}{lr}\text { Menggunakan } & \text { handphone } \\
\text { Samsung A21 untuk } \\
\text { memperlihatkan keadaan } \\
\text { desain, lingkungan, dan recorder } \\
\text { sebagai data wawancara dalam } \\
\text { membantu kajian analisis. }\end{array}$ & $\begin{array}{l}\text { Menyesuaikan dan } \\
\text { dapat terdengar } \\
\text { baik dalam analisis. }\end{array}$ & $\begin{array}{l}\text { Wawancara } \\
\text { kepada } \\
\text { penghuni } \\
\text { bangunan } \\
\text { pada saat } \\
\text { siang hari. }\end{array}$ & $\begin{array}{l}\text { Pencatatan pada } \\
\text { saat wawancara. }\end{array}$ \\
\hline Alat tulis dan Note. & $\begin{array}{l}\text { Manajemen data untuk } \\
\text { pencatatan termal, kelembaban, } \\
\text { dan angin, yang dapat memberi } \\
\text { pengaruh dalam kajian } \\
\text { penelitian termal. }\end{array}$ & Menyesuaikan & $\begin{array}{l}\text { Sepanjang } \\
\text { observasi } \\
\text { lapangan } \\
\text { berlangsung }\end{array}$ & $\begin{array}{l}\text { Pencatatan pada } \\
\text { saat pengukuran. }\end{array}$ \\
\hline
\end{tabular}

Metode yang perlu diperhatikan selanjutnya adalah posisi titik pengukuran, hal ini penting karena akan menghasilkan hasil penelitian yang cukup berbeda antara titik satu dan lainnya. Contohnya titik pengukuran pada posisi sisi barat tentu akan berbeda pada sisi timur, termasuk juga perbedaan sisi-sisi lainnya. Sedangkan titik pengukuran pada area luar bangunan sebaiknya dipilih yang tidak terkena langsung cahaya Matahari, misalnya berada di selasar, atau tempat yang teduh.

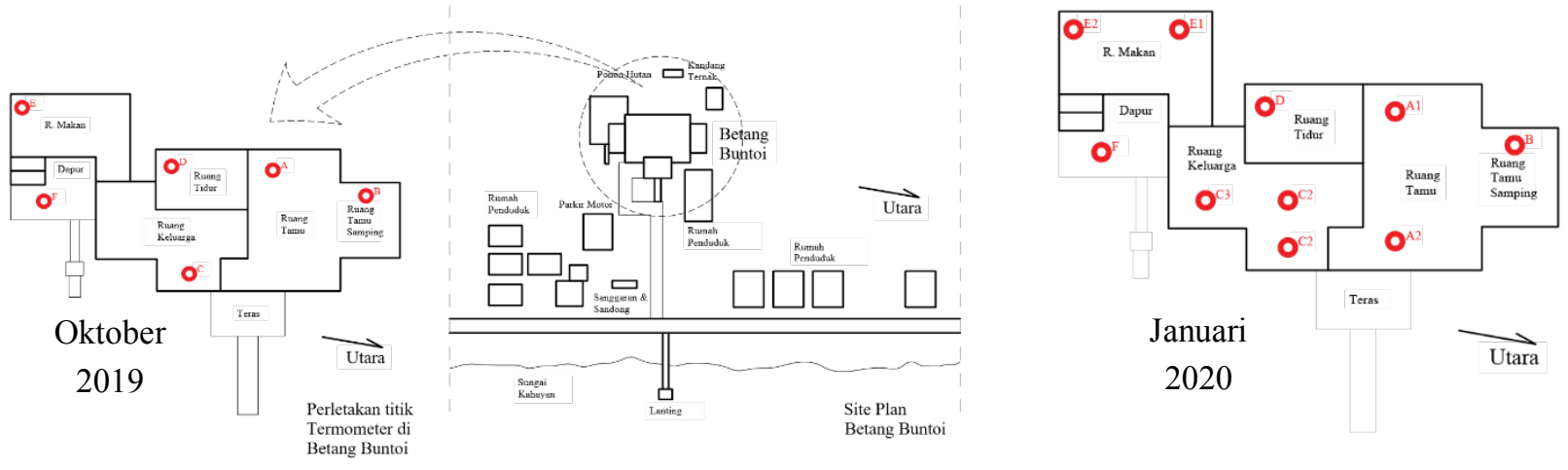

Gambar 2. Posisi perletakan titik pengukuran pada Bentang Buntoi di denah

(Sumber: Observasi, 2020)

Titik pengukuran terlihat berbeda posisi karena saat survei pertama tidak memungkinkan ketersediaan alat, sehingga pada survei lapangan selanjutnya akan dilengkapi kekurangan tersebut dengan menambah jumlah alat pada observasi lapangan kedua.
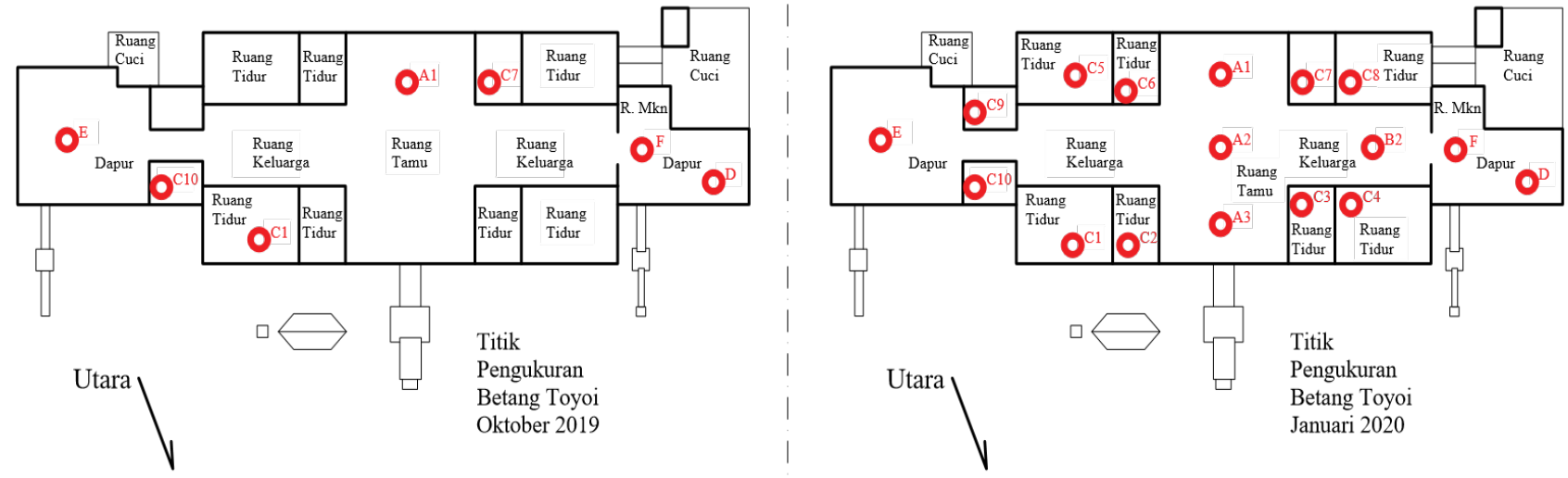

Gambar 3. Posisi perletakan titik pengukuran pada Bentang Toyoi di denah

(Sumber: Observasi, 2020)

Titik pengukuran juga terlihat berbeda posisi dengan permasalahan yang sama saat studi kasus pada Rumah (Huma) Gantung Buntoi. 

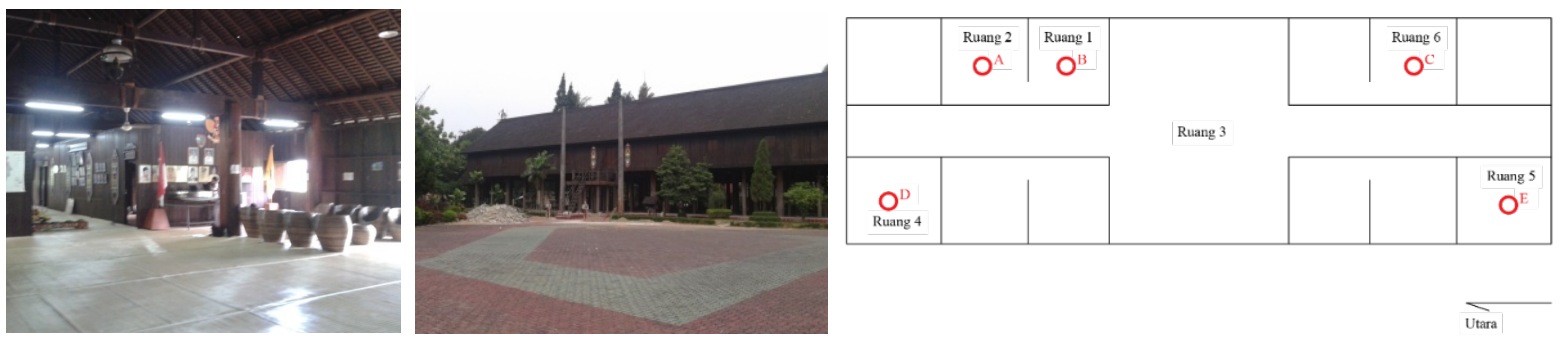

Gambar 4. Posisi perletakan titik pengukuran Bentang TMII (Taman Mini Indonesia Indah) pada denah tidak memiliki perbedaan (Sumber: Observasi, 2020)

Untuk metode wawancara akan menggunakan daftar pertanyaan terkait dengan Skala ASHRAE, agar dapat di ukur secara kuantitatif, berikut skala pertanyaannya.

Tabel 2. Kuisoner menggunakan Skala ASHRAE Tahun 2017 pada Betang Buntoi dan Betang Toyoi (Sumber: Data, 2020)

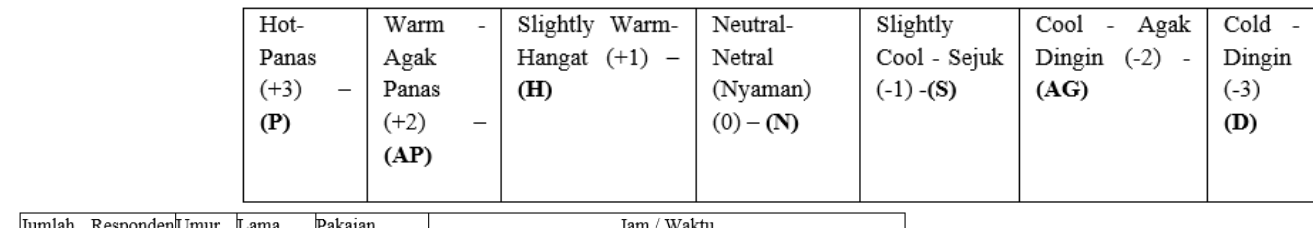

\begin{tabular}{|c|c|c|c|c|c|c|c|c|c|c|c|c|c|c|}
\hline Jumlah Responden $[\bar{x}$ & Umur & Lama & Pakaian & & & & & & $\mathrm{m} / \mathrm{Wa}$ & & & & & \\
\hline & & & & 0 & 08.0 & 009. & 010.0 & 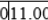 & 0112.00 & $\frac{113.0}{13.0}$ & 0114.00 & $\sqrt{15.00}$ & 016.00 & 017.00 \\
\hline Individu 1 (Wanita) & 71 & 60 th & Daster & (N) & $(\mathrm{N})$ & $(\mathrm{N})$ & (N) & (N) & (N) & $(\mathbb{N})$ & (N) & $(\mathrm{N})$ & (N) & $(\mathrm{N})$ \\
\hline Individu 2 (pria) & 17 & 2 th & $\begin{array}{l}\text { Kaos, celana } \\
\text { panjang }\end{array}$ & (N) & (N) & $(\mathrm{N})$ & (N) & (N) & $(\mathrm{N})$ & (N) & (N) & $(\mathrm{N})$ & $(\mathrm{N})$ & (N) \\
\hline Jumlah Responden & Umur & Lama & Pakaian & & & & & & $\mathrm{m} / \mathrm{Wa}$ & & & & & \\
\hline & & & & 07.00 & 08.0 & 009 & 10.0 & 011.0 & 12.00 & 13.0 & 014.00 & 15.00 & 016.00 & 017.00 \\
\hline & & & & & & & & & & & & & & \\
\hline Individu 1 (wanita) & 70 & 70 th & Daster & $(\mathrm{N})$ & (N) & $(\mathrm{N})$ & (N) & (N) & (N) & (N) & (N) & (N) & (N) & (N) \\
\hline Individu 2 (wanita) & 80 & 80 th & Daster & (N) & $(\mathrm{N})$ & $(\mathrm{N})$ & (N) & (N) & (N) & $(\mathrm{N})$ & $(\mathrm{N})$ & $(\mathrm{N})$ & $(\mathrm{N})$ & (N) \\
\hline Individu 3 (wanita) & 60 & 60 th & Daster & (N) & (N) & (N) & (N) & $(\mathrm{N})$ & $(\mathrm{N})$ & (N) & $(\mathrm{N})$ & (N) & $(\mathrm{N})$ & (N) \\
\hline Individu 4 (wanita) & 54 & 30 th & Daster & (S) & (S) & (S) & (S) & $(\mathrm{N})$ & (N) & $(\mathrm{N})$ & $(\mathrm{N})$ & (N) & $(\mathrm{N})$ & (N) \\
\hline Individu 5 (wanita) & 21 & 3 th & $\begin{array}{l}\text { Kaos, kain, } \\
\text { celana }\end{array}$ & (S) & (S) & (S) & (S) & (N) & (N) & $(\mathrm{N})$ & $(\mathrm{N})$ & (N) & $(\mathrm{N})$ & (N) \\
\hline Individu 6 (Pria) & 60 & 5 th & $\begin{array}{l}\text { Kaos, Celana } \\
\text { Pendek }\end{array}$ & (S) & (S) & (S) & (S) & $(\mathrm{N})$ & $(\mathbb{N})$ & $(\mathrm{N})$ & $(\mathrm{N})$ & (N) & $(\mathrm{N})$ & (N) \\
\hline Individu 7 (Pria) & 23 & 3 th & $\begin{array}{l}\text { Kaos, Celana } \\
\text { Panjang }\end{array}$ & $(\mathrm{N})$ & $(\mathbb{N})$ & $(\mathrm{N})$ & (N) & $(\mathrm{N})$ & $(\mathrm{N})$ & $(\mathrm{N})$ & $(\mathrm{N})$ & (N) & $(\mathrm{N})$ & $(\mathrm{N})$ \\
\hline
\end{tabular}

Hasil Kuisoner pada rumah Betang Buntoi terlihat didominasi dengan hasil jawaban bobot angka " 0 " yaitu nyaman (Data Januari 2020)
Hasil Kuisoner pada rumah Betang Toyoi terlihat didominasi dengan hasil jawaban bobot angka "0" yaitu nyaman (Data Januari 2020)

Skala ASHRAE digunakan untuk menentukan titik netral responden (Alfata et al., 2014), untuk itu skala ini cukup cocok digunakan dalam kuisoner yang bertujuan mengukur sensasi termal. Tingkat skala sensasi termal dibedakan menjadi 7 , dimana perhitungannya +3 adalah panas, +2 adalah agak panas, +1 adalah hangat, 0 adalah nyaman, -1 sejuk, -2 agak dingin, dan -3 dingin (ASHRAE, 2017). Sedangkan daftar pertanyaannya hanya satu yaitu "bagaimana perasaan ketika menempati bangunan ini", dengan memberikan juga alternatif jawaban kepada penghuni, yaitu "apakah panas, atau agak panas, hangat, nyaman, sejuk, agak dingin, dan dingin". Tentunya pertanyaan diimbangi juga dengan pertanyaan lain yang dapat menjadi pertimbangan di luar aspek termal namun tetap terkait secara tidak langsung seperti misalnya, "berapa lama tinggal dibangunan ini" (pertanyaan yang mengarahkan proses adaptasi pengguna terhadap bangunan), pertanyaan tentang "umur", dan catatan pakaian yang digunakan saat wawancara berlangsung (terkait keadaan pengguna saat dilakukan wawancara). Wawancara dilakukan pada saat siang dan sore hari, tentunya juga saat keadaan kondusif serta tidak terpengaruh gangguan lainnya.

Observasi dilakukan dengan pengukuran setiap ruangan baik didalam maupun diluar bangunan, dan data yang dikumpulkan berupa angka agar dapat dianalisis secara induktif. Rincian penggunaan metode dibagi menjadi dua variabel, variabel pertama adalah ruang-ruang didalam serta ruang diluar bangunan, untuk variabel kedua terkait dengan suhu. Populasi yang dipilih adalah beberapa objek yang mewakili rumah Suku Dayak di Kalimantan Tengah yang masih berdiri, serta objek yang berada diluar pulau Kalimantan sebagai pembanding. 


\subsection{Metode Analisis Data}

Untuk memahami secara kuantitatif sensasi termis manusia terhadap stimulus yang diterimanya terkait iklim, suhu, kelembaban, angin, orientasi, tata letak, ventilasi, vegetasi, maka diekspresikan dalam angka yang dikaji pada teori yang telah ada. Teori tersebut berkaitan dengan karakteristik dan kenyamanan termal, analisis induktif (dari bawah) dilakukan secara deskriptif bersamaan proses pengumpulan data. Secara umum tahapan analisis meliputi pengelompokan informasi yang mirip atau kurang lebih berhubungan, sehingga memunculkan kesimpulan pengukuran, kemudian analisis hubungan yang berkaitan dengan judul untuk memunculkan konsep, atau dialog berkaitan dengan konsep untuk menemukan temuan baru (grounded theory). Metode juga menetapkan kesimpulan akhir dari karakteristik kenyamanan termal dalam ruangan dengan perbandingan mengenai objek fisik yang ditemukan pada komplek Huma (Rumah) Gantung Buntoi, Betang Toyoi, dan Betang modern Taman Mini Indonesia Indah.

\section{Hasil dan Pembahasan}

Lokasi Betang Buntoi (Huma Gantung) berada di desa Buntoi Kabupaten Kuala Kapuas, tepatnya pada tepi sungai Kahayan. Koordinat Lokasi Betang Buntoi adalah $2^{\circ} 48^{\prime} 34.9^{\prime \prime} \mathrm{S} 114^{\circ} 12^{\prime} 05.5^{\prime \prime E}$. Kabupaten Kapuas beriklim tropis lembab dengan temperatur $21^{\circ} \mathrm{C}-23^{\circ} \mathrm{C}$ dan maksimal $36^{\circ} \mathrm{C}$, curah hujan berkisar 223-604 mm tiap tahun (Wikipedia: Kabupaten Kapuas). Kondisi temperatur udara secara makro $32^{\circ} \mathrm{C}$ bulan Oktober hingga $31^{\circ} \mathrm{C}$ bulan Januari, kecepatan angin $12 \mathrm{~m} / \mathrm{s}$ dari Oktober ke Januari, dan rata-rata kelembaban (Rh) berkisar 68\% bulan Oktober ke 60\% di November (cuaca Kuala Kapuas dari Mirbig.net).

Sedangkan untuk Betang Toyoi berada di Tumbang Malahoi tepatnya tepi Sungai Baringai (cabang sungai besar Kahayan), dan keduanya sama-sama berada di Provinsi Kalimantan Tengah. Koordinat Lokasi Betang Toyoi adalah $1^{\circ} 13^{\prime} 03.6^{\prime \prime S} 113^{\circ} 31^{\prime} 19.5^{\prime \prime E}$. Rumah Betang Buntoi merupakan suatu komplek yang terdiri dari satu bangunan utama dan beberapa bangunan penunjang. Dari dimensi, rumah Betang Buntoi memiliki bentang lebar yang hampir sama dengan Betang Toyoi tetapi memiliki panjang yang lebih kecil. Betang Buntoi memiliki lebar sekitar \pm 10 meter, sedangkan panjang \pm 26 meter dengan tinggi panggung \pm 4 meter. Dan untuk Betang Toyoi memiliki lebar sebesar \pm 10 meter, sedangkan panjang \pm 36 meter dengan ketinggian panggung \pm 2.5 meter dari permukaan tanah. Bangunan ini mengalami proses pembangunan dan saat ini telah menjadi bangunan tradisional yang dilindungi pemerintah.
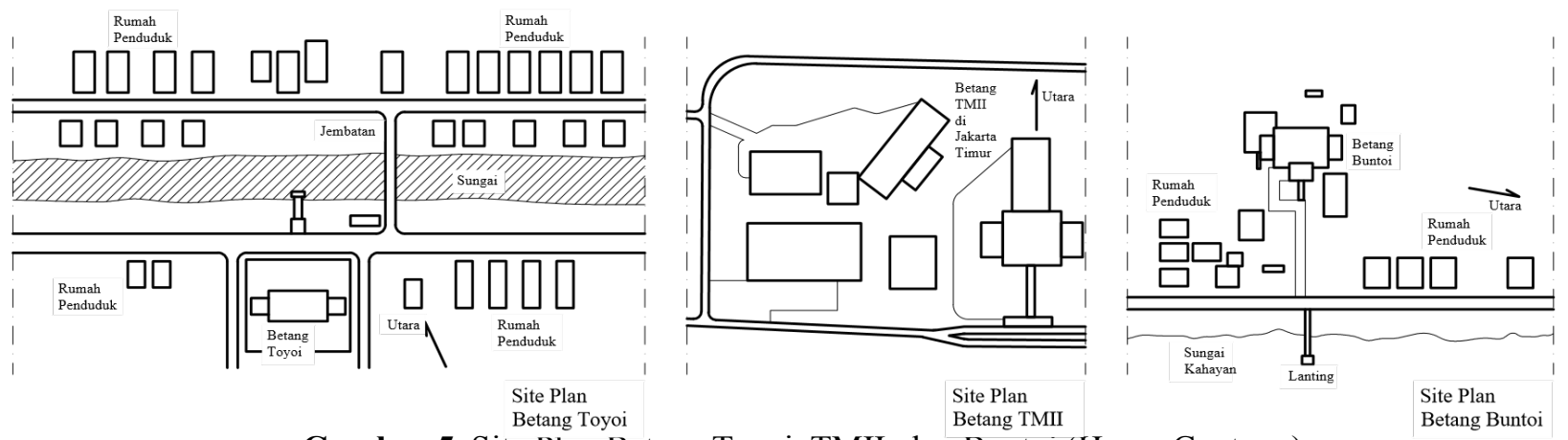

Gambar 5. Site Plan Betang Toyoi, TMII, dan Buntoi (Huma Gantung).

(Sumber: Observasi Lapangan, 2020)

Untuk rumah Betang Suku Dayak Taman Mini Indonesia Indah (TMII) berada di Jakarta Timur yang pada lokasinya tidak terdapat aliran sungai. Koordinat Lokasi Betang Taman Mini Indonesia Indah adalah 6¹7'58.9"S $106^{\circ} 53^{\prime} 58.7^{\prime \prime E}$. Kondisi Iklim Jakarta Timur selalu beriklim panas dengan suhu rata-rata sepanjang tahun sekitar $27^{\circ} \mathrm{C}$ (Wikipedia: Jakarta Timur).
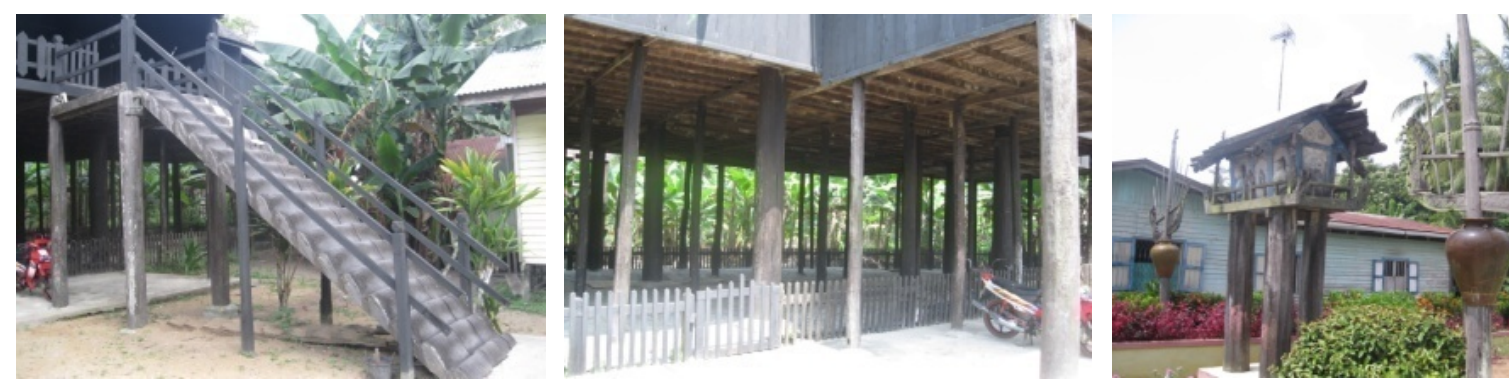

Gambar 6. Bagian Bawah (Huma) Gantung Buntoi

(Sumber: Observasi Lapangan, 2020) 
Area bawah dapat mengalirkan udara dan tentunya juga mempengaruhi kondisi termal didalam bangunan.
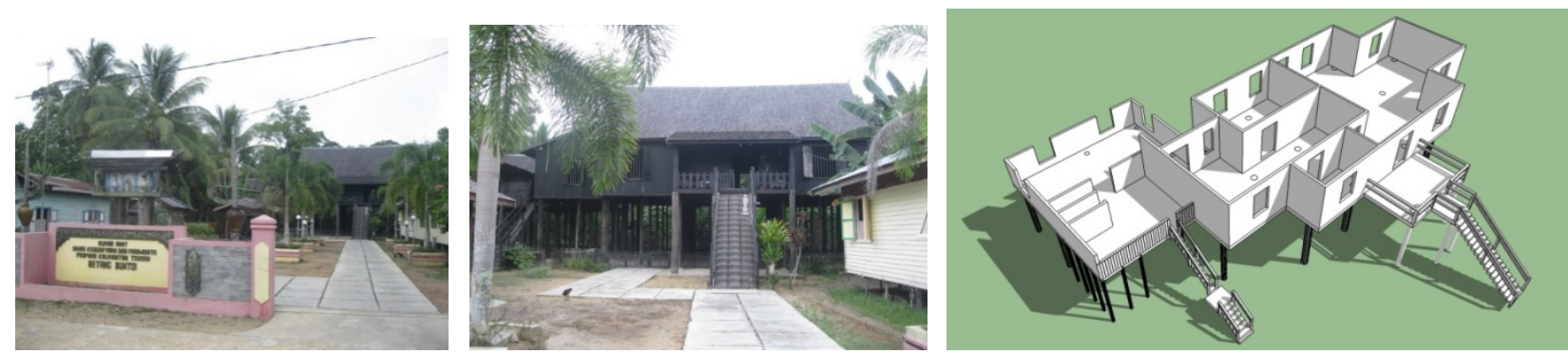

Gambar 7. Tampak depan rumah (Huma) Gantung Buntoi

(Sumber: Observasi Lapangan, 2020)

Simulasi komputer Rumah (Huma) Gantung Buntoi, nampak terlihat konfigurasi ruang dari proyeksi perspektif perpotongan denah, serta tampilan fasad, tangga, dan area bawah bangunan Huma Gantung Buntoi.
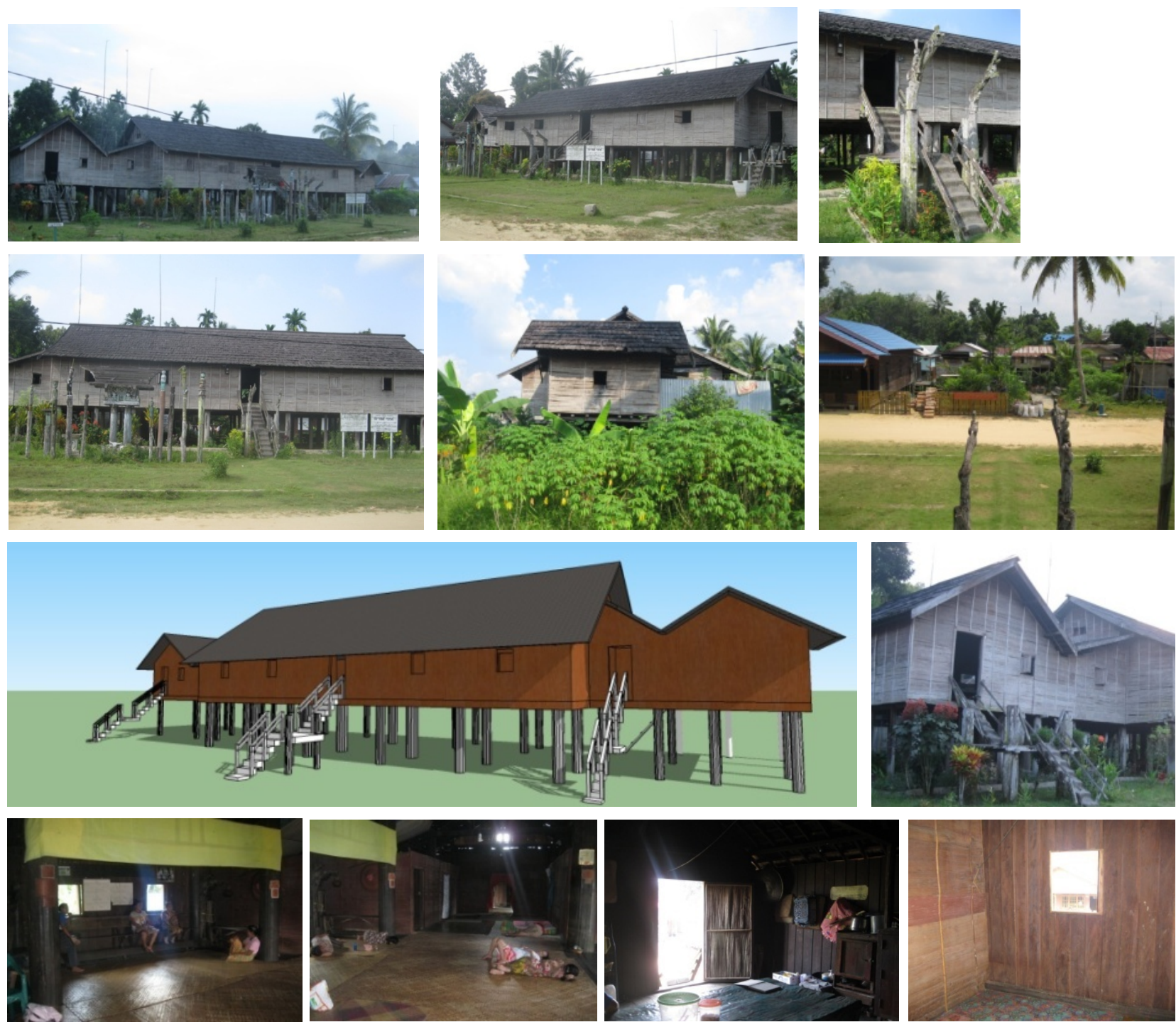

Gambar 8. Tampak depan Betang Toyoi, 3d, dan Interiornya

(Sumber: Observasi Lapangan, 2020)

Terlihat Eksterior dan Interior dari Betang Toyoi, nampak juga penggambaran ulang 3d dalam memperjelas bentuk Betang Toyoi beserta dimensi bukaan yang dimilikinya. 
Tabel 3. Kelembaban dan Angin Oktober dan Januari di Betang Buntoi

(Sumber: Data lapangan, 2019, 2020)

\begin{tabular}{|c|c|c|c|c|c|c|c|c|c|c|c|c|}
\hline Ruang & $\mathrm{Jam}$ & 7 & 8 & 9 & 10 & \begin{tabular}{|l|}
11 \\
\end{tabular} & 12 & \begin{tabular}{|l|l|}
13 & \\
\end{tabular} & 14 & 15 & 16 & 17 \\
\hline \multirow{8}{*}{$\begin{array}{l}\text { Ruang } \\
\text { di sisi } \\
\text { barat } \\
\text { (\%) }\end{array}$} & R. Tamu (A) & 74 & 72 & 70 & 64 & 60 & 56 & 52 & 55 & 60 & 64 & 65 \\
\hline & R. Tamu (A) & 75 & 70 & 67 & 64 & 65 & 71 & \begin{tabular}{|l|}
55 \\
\end{tabular} & 60 & 62 & 67 & 70 \\
\hline & R Tamu Samping (B) & 75.5 & 68.5 & 65 & 64 & 60 & 55 & 51.4 & 59 & 61 & 66 & 65.1 \\
\hline & R. Tamu Samping (B) & 76 & 68.5 & 65 & 64 & 60 & 69 & \begin{tabular}{|l|}
58 \\
\end{tabular} & 61 & \begin{tabular}{|l|l|}
62 & \\
\end{tabular} & 66 & 70 \\
\hline & $\begin{array}{l}\text { R. Tidur (D) } \\
\end{array}$ & 74 & 68 & 65.5 & 61.5 & 62.5 & 55.3 & \begin{tabular}{|l|l|}
50.5 \\
\end{tabular} & 59.7 & \begin{tabular}{|l|l}
61 & 6 \\
\end{tabular} & 64.5 & 65.3 \\
\hline & R. Tidur (D) & 74 & 68 & 65 & 61 & 62.5 & 55.5 & 59.5 & 616 & \begin{tabular}{|l|l|l}
64.5 & 6 \\
\end{tabular} & 65.5 & 70 \\
\hline & R. Makan (E) & 75 & 67.9 & 64.4 & 60.5 & 59.5 & 55.2 & 55 & \begin{tabular}{l|}
60.3 \\
\end{tabular} & \begin{tabular}{|l|l}
61 & 6 \\
\end{tabular} & 62.5 & 65.5 \\
\hline & R. Makan (E) & 75 & 68 & 65 & 60.5 & \begin{tabular}{|l|}
59 \\
\end{tabular} & 55 & |51.5 & 55.5 & \begin{tabular}{|l|l}
63 & 6 \\
\end{tabular} & \begin{tabular}{l|l}
67 & \\
\end{tabular} & 72 \\
\hline \multirow{4}{*}{$\begin{array}{l}\text { Ruang } \\
\text { di sisi } \\
\text { timur } \\
\text { (\%) }\end{array}$} & R. Keluarga (C) & 74 & 68 & 64.5 & 61 & 60 & 55.5 & 50.5 & 60.5 | & \begin{tabular}{l|l}
61.2 & \\
\end{tabular} & 64 & 65 \\
\hline & R. Keluarga (C) & 74 & 68 & 64.5 & 61 & 60 & 55.5 & 61 & 62 & 64 & 65 & 70 \\
\hline & Dapur (F) & 74 & 72 & 70 & 64 & 60 & 56 & 50 & 58 & \begin{tabular}{l|l}
59 & 6 \\
\end{tabular} & 64 & 65 \\
\hline & Dapur (F) & 75 & 72 & 60 & \begin{tabular}{|l|}
58 \\
\end{tabular} & \begin{tabular}{|l|}
57 \\
\end{tabular} & 55 & 52.5 & 55.5 & 63 & 67 & 71 \\
\hline \multicolumn{2}{|r|}{ Outdoor } & 76 & 72 & 60 & 58 & \begin{tabular}{|l|}
57 \\
\end{tabular} & 55 & 45 & 51.5 & $55.6 \quad 6$ & 63 & 67 \\
\hline \multicolumn{2}{|r|}{ Outdoor } & 77 & 73 & 65 & 61 & 62.5 & 55.5 & 59.5 & 61 & \begin{tabular}{l|l}
64.5 & 6 \\
\end{tabular} & 65.5 & 70 \\
\hline \multicolumn{2}{|r|}{ keterangan } & & & & & & & & & & & \\
\hline
\end{tabular}

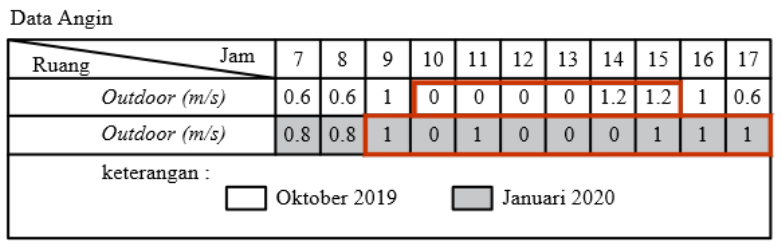

Kesimpulan
\begin{tabular}{|l|c|c|c|c|c|c|}
\hline \multirow{3}{*}{ Keterangan } & \multicolumn{3}{|c|}{$\begin{array}{c}\text { Musim Kemarau } \\
\text { (Oktober 2019) }\end{array}$} & \multicolumn{3}{c|}{$\begin{array}{c}\text { Musim Hujan } \\
\text { (Januari 2020) }\end{array}$} \\
\cline { 2 - 6 } & \multicolumn{3}{|c|}{ Kelembaban (\%) } & \multirow{2}{*}{ Rata $\left.^{2} \%\right)$} & Kelembaban (\%) & \multirow{2}{*}{ Rata $\left.^{2} \%\right)$} \\
\cline { 2 - 6 } & tertinggi & terendah & & tertinggi & terendah & \\
\hline di dalam bangunan (indoor) & 75.5 & 50 & 63.2 & 76 & 51.5 & 64.1 \\
\hline di luar bangunan (outdoor) & 76 & 45 & 60 & 77 & 55.5 & 64.9 \\
\hline kecepatan angin (m/s) & 1.2 & 0 & 0.56 & 1 & 0 & 0.6 \\
\hline
\end{tabular}

Berdasarkan tabel diatas disimpulkan bahwa pada bulan Oktober didalam bangunan memiliki nilai kelembaban tertinggi yaitu 75,5\% pada pagi hari jam 07.00 WIB dan yang terendah adalah 50\% pada jam $13.00 \mathrm{WIB}$, untuk kondisi luar bangunan tertinggi adalah $76 \%$ pada Jam 07.00 WIB dan terendah adalah $45 \%$ pada pukul 13.00 WIB. Diketahui juga bahwa untuk daerah tropis, kelembaban udara relatif yang dianjurkan antara $40 \%-50 \%$, tetapi untuk ruangan yang jumlah orangnya padat seperti ruang pertemuan, kelembaban udara relatif masih diperbolehkan berkisar antara 55\% - 60\% (SNI 03-6572-2001, 2001). Hal ini menunjukkan bahwa saat pagi hari pada bulan Oktober Betang Buntoi memiliki kelembaban yang tidaklah nyaman baik pada keadaan luar maupun dalam. Berbeda saat keadaan siang dan sore hari, kelembaban pada Rumah Betang Buntoi masih dapat dikategorikan nyaman, baik keadaan didalam maupun diluar bangunan.

Untuk Bulan Januari Betang Buntoi memiliki nilai kelembaban tertinggi yaitu 76\% pada pagi hari jam 07.00 WIB, dan yang terendah adalah 51,5\% pada siang hari pada Jam 13.00 WIB. sedangkan untuk kondisi ruang luar kelembaban bangunan yang tertinggi adalah $77 \%$ pada pagi hari dan terendah adalah $55,5 \%$ pada saat siang hari. Berdasarkan hal tersebut dapat disimpulkan berdasarkan tori yang ada makapada bulan Januari kondisi Rumah Betang Buntoi relatif lembab saat pagi hari, dan cukup nyaman saat menjelang siang dan sore hari. Terlihat juga besar kecepatan angin yang masuk dengan nilai tertinggi sebesar $1.2 \mathrm{~m} / \mathrm{s}$ dengan rata-rata $0,56 \mathrm{~m} / \mathrm{s}$ pada bulan oktober, serta nilai tertinggi pada bulan januari sebesar $1 \mathrm{~m} / \mathrm{s}$ dengan rata-rata $0,6 \mathrm{~m} / \mathrm{s}$.

Tabel 4. Kelembaban dan Angin Oktober 2019 dan Januari 2020, di Betang Toyoi (Sumber: Data Lapangan, 2019, 2020)

\begin{tabular}{|c|c|c|c|c|c|c|c|c|c|c|c|c|}
\hline Ruang & Jam & 7 & 8 & 9 & 10 & 11 & 12 & \begin{tabular}{|l|}
13 \\
\end{tabular} & 14 & 15 & 16 & 17 \\
\hline \multirow{6}{*}{$\begin{array}{l}\text { Ruang } \\
\text { di sisi } \\
\text { barat } \\
(\%)\end{array}$} & R. Tamu (A) & 75 & 70 & 67 & 64 & 65 & 71 & 62 & 64 & 62 & 61 & 64 \\
\hline & R. Tamu (A) & 77 & 73 & 69 & 63 & 65 & 71 & 66 & 67 & 68 & 68 & 70 \\
\hline & K. Tidur (C) & 71 & 69 & 67 & 67.5 & 70 & 65.6 & 61.4 & 60.2 & 59.2 & 63.6 & 67.8 \\
\hline & K. Tidur (C) & 73 & 70 & 66 & 65 & 70 & 65.6 & 66 & 61 & 62 & 66 & 70 \\
\hline & Dapur 2 (D) & 73 & 70 & 66.7 & 66.6 & 65.2 & 61.5 & 58 & 52.5 & 55.5 & 60 & 65.5 \\
\hline & Dapur 2 (D) & 78 & 75 & 70 & 65 & 72 & 68 & 67 & 62 & 68 & 69 & 71 \\
\hline \multirow{6}{*}{$\begin{array}{l}\text { Ruang } \\
\text { di sisi } \\
\text { timur } \\
(\%)\end{array}$} & K. Tidur $(C)$ & 71.2 & 69.5 & 68 & 65.6 & 65.7 & 62.5 & 64.7 & 60.3 & 61.6 & 62.5 & 68.5 \\
\hline & K. Tidur (C) & 71 & 72 & 67 & 65 & 70 & 65.6 & 67 & 61 & 67 & 66 & 70 \\
\hline & Dapur 1 (E) & 73 & 68 & 66.2 & 69.6 & 70 & 64.5 & 59.5 & 63.9 & 59.5 & 60.3 & 65 \\
\hline & Dapur 1 (E) & 72 & 64 & 67 & 60 & 72 & 69 & 64 & 61 & 63 & 66 & 70 \\
\hline & Ruang Mkn (F) & 75 & 73 & 67.5 & 65 & 63 & 61.6 & \begin{tabular}{|l|l}
56 \\
\end{tabular} & 52.7 & 59 & 64 & 65 \\
\hline & Ruang Mkn (F) & 71 & 69 & 66 & 62 & 72 & 68 & 67 & 62 & 68 & 69 & 71 \\
\hline \multirow{2}{*}{$\begin{array}{l}\text { Ruang di } \\
\text { tengah (\%) }\end{array}$} & R. Keluarga (B) & 75 & 70 & 67 & 64 & 65 & 71 & 62 & 64 & 62 & 61 & 64 \\
\hline & R. Keluarga (B) & 73 & 70 & 66.7 & 66.6 & 65.2 & 61.5 & 52 & 51 & 65 & 64 & 69 \\
\hline \multicolumn{2}{|c|}{ Outdoor } & 72 & 71 & 69 & 68 & 57 & 59 & 51.5 & 54.5 & 59.6 & 64.5 & 65.3 \\
\hline \multicolumn{2}{|c|}{ Outdoor } & 74 & 72 & 72 & 70 & 60 & 55 & 54.5 & 60 & 59.6 & 64.5 & 70 \\
\hline \multicolumn{13}{|c|}{ keterangan } \\
\hline
\end{tabular}

\begin{tabular}{l} 
Data Angin \\
\begin{tabular}{|c|c|c|c|c|c|c|c|c|c|c|c|}
\hline Ruang Jam & 7 & 8 & 9 & 10 & 11 & 12 & 13 & 14 & 15 & 16 & 17 \\
\hline Outdoor $(\mathrm{m} / \mathrm{s})$ & 0.6 & 0.6 & 0.6 & 0.6 & 0.9 & 0 & 0.6 & 0 & 0 & 1 & 0 \\
\hline Outdoor $(\mathrm{m} / \mathrm{s})$ & 0.5 & 0.7 & 0.6 & 0.6 & 0.9 & 0 & 0 & 0 & 0 & 1 & 0 \\
\hline keterangan : \\
$\square$ Oktober 2019 \\
$\square$ Januari 2020
\end{tabular} \\
\hline
\end{tabular}

Kesimpulan
\begin{tabular}{|l|c|c|c|c|c|c|}
\hline \multirow{3}{*}{ Keterangan } & \multicolumn{3}{|c|}{$\begin{array}{c}\text { Musim Kemarau } \\
\text { (Oktober 2019) }\end{array}$} & \multicolumn{3}{c|}{$\begin{array}{c}\text { Musim Hujan } \\
\text { (Januari 2020) }\end{array}$} \\
\cline { 2 - 7 } & \multicolumn{2}{|c|}{ Kelembaban (\%) } & \multirow{2}{*}{ Rata $^{2}(\%)$} & \multicolumn{2}{|c|}{ Kelembaban (\%) } & \multirow{2}{*}{ Rata $^{2}(\%)$} \\
\cline { 2 - 7 } & tertinggi & terendah & & tertinggi & terendah & \\
\hline di dalam bangunan (indoor) & 75 & 52.5 & 65 & 78 & 51 & 67.2 \\
\hline di luar bangunan (outdoor) & 72 & 51.5 & 62.8 & 74 & 54.5 & 64.6 \\
\hline kecepatan angin (m/s) & 1 & 0 & 0.44 & 1 & 0 & 0.39 \\
\hline
\end{tabular}


Berdasarkan data pada bulan Oktober didalam bangunan memiliki nilai kelembaban tertinggi sebesar 75\% pada jam 07.00 WIB dan yang terendah adalah 52,5\% pada jam $14.00 \mathrm{WIB}$, untuk kondisi luar kelembaban bangunan yang tertinggi pada Jam 07.00 WIB dengan besar kelembaban 72\% dan terendah adalah 51,5\% pada pukul 13.00 WIB. Untuk bulan Januari Kelembaban yang tertinggi adalah sebesar 78\% pada jam 07.00 WIB dan yang terendah $51 \%$ pada pukul 14.00 WIB. Sedangkan untuk kondisi ruang luar kelembaban rumah tertinggi adalah $74 \%$ jam 07.00 WIB, dan yang terendah 54,5\% pada pukul 13.00 WIB. Maka dari data tersebut disimpulkan Betang Toyoi memiliki kelembaban didalam bangunan yang tidak nyaman pada saat pagi dan siang hari pada bulan Oktober dan Januari. Sedangkan untuk keadaan kelembaban diluar bangunan Betang Toyoi juga memiliki kelembaban yang tidak nyaman baik keadaan pagi dan siang hari di bulan Oktober dan Januari. Terlihat juga besar kecepatan angin yang masuk dengan nilai tertinggi sebesar $1 \mathrm{~m} / \mathrm{s}$ dengan rata-rata $0,44 \mathrm{~m} / \mathrm{s}$ pada bulan Oktober, serta nilai tertinggi pada bulan januari sebesar $1 \mathrm{~m} / \mathrm{s}$ dengan rata-rata $0,39 \mathrm{~m} / \mathrm{s}$.

Tabel 5. Hasil Kelembaban dan Angin November 2019 dan Januari 2020 (Kemarau dan Hujan) di Betang TMII (Taman Mini Indonesia Indah) (Sumber: Data lapangan, 2019, 2020)

\begin{tabular}{|c|c|c|c|c|c|c|c|c|c|c|c|c|}
\hline Ruang & $\mathrm{Jam}$ & 7 & 8 & 9 & 10 & 11 & 12 & 13 & 14 & 15 & 16 & 17 \\
\hline \multirow{6}{*}{$\begin{array}{l}\text { Ruang } \\
\text { di sisi } \\
\text { barat } \\
(\%)\end{array}$} & Ruang 3 & 70 & 70 & 67 & 67 & 65 & 60 & 72 & 70 & 80 & 91 & 85 \\
\hline & Ruang 3 & 72 & 73 & 65 & 68 & 64 & 60 & 65 & 64 & 68 & 65 & 70 \\
\hline & Ruang 4 & 70 & 70 & 67 & 67 & 65 & 60 & 72 & 70 & 80 & 90 & 85 \\
\hline & Ruang 4 & 71 & 75 & 64 & 68 & 67 & 62 & 64 & 61 & 59 & 65 & 72 \\
\hline & Ruang 5 & 70 & 70 & 67 & 67 & 65 & 61 & 72 & 70 & 80 & 91 & 85 \\
\hline & Ruang 5 & 69 & 70 & 67 & 65 & 63 & 59 & 62 & 63 & 57 & 66 & 69 \\
\hline \multirow{6}{*}{$\begin{array}{l}\text { Ruang } \\
\text { di sisi } \\
\text { timur } \\
(\%)\end{array}$} & Ruang 1 & 70 & 70 & 67 & 67 & 65 & 59 & 72 & 70 & 80 & 92 & 85 \\
\hline & Ruang 1 & 73 & 70 & 69 & 67 & 61 & 59 & 69 & 64 & 60 & 65 & 68 \\
\hline & Ruang 2 & 70 & 70 & 67 & 67 & 65 & 60 & 72 & 70 & 80 & 90 & 85 \\
\hline & Ruang 2 & 70 & 72 & 67 & 68 & 65 & 60 & 63 & 62 & 67 & 65 & 70 \\
\hline & Ruang 6 & 70 & 70 & 67 & 67 & 65 & 60 & 72 & 70 & 80 & 91 & 85 \\
\hline & Ruang 6 & 71 & 70 & 69 & 67 & 63 & 60 & 59 & 62 & 65 & 65 & 70 \\
\hline \multicolumn{2}{|c|}{ Outdoor } & 67 & 67 & 62 & 60 & 65 & 60 & 70 & 70 & 80 & 95 & 80 \\
\hline \multicolumn{2}{|c|}{ Outdoor } & 70 & 71 & 63 & 61 & 64 & 60 & 71 & 65 & 67 & 66 & 72 \\
\hline \multicolumn{2}{|r|}{ keterangan } & & & & & & & & & & & \\
\hline
\end{tabular}

\begin{tabular}{l} 
Data Angin \\
\begin{tabular}{|c|c|c|c|c|c|c|c|c|c|c|c|}
\hline Ruang Jam & 7 & 8 & 9 & 10 & 11 & 12 & 13 & 14 & 15 & 16 & 17 \\
\hline Outdoor $(\mathrm{m} / \mathrm{s})$ & 0.1 & 0.3 & 0.1 & 0 & 0 & 0 & 0.4 & 2 & 2 & 3 & 1 \\
\hline Outdoor $(\mathrm{m} / \mathrm{s})$ & 0.6 & 0 & 0.6 & 0 & 0 & 0 & 0 & 0 & 0 & 1 & 1 \\
\hline keterangan : November 2019 \\
$\square$ \\
$\square$
\end{tabular} \\
\hline
\end{tabular}

Kesimpulan
\begin{tabular}{|l|c|c|c|c|c|c|}
\hline \multirow{3}{*}{ Keterangan } & \multicolumn{3}{|c|}{ November 2019) } & \multicolumn{3}{c|}{$\begin{array}{c}\text { Musim Hujan } \\
\text { (Januari 2020) }\end{array}$} \\
\cline { 2 - 7 } & \multicolumn{3}{|c|}{ Kelembaban (\%) } & \multirow{2}{*}{ Rata $^{2} \%$} & Kelembaban (\%) & \multirow{2}{*}{ Rata $\left.^{2} \%\right)$} \\
\cline { 2 - 7 } & tertinggi & terendah & & tertingi & terendah & \\
\hline di dalam bangunan (indoor) & 92 & 59 & 72.4 & 75 & 59 & 65.8 \\
\hline di luar bangunan (outdoor) & 95 & 60 & 70.5 & 71 & 61 & 66.3 \\
\hline kecepatan angin (m/s) & 3 & 0 & 0.8 & 1 & 0 & 0.3 \\
\hline
\end{tabular}

Berdasarkan data pada bulan November didalam bangunan memiliki nilai kelembaban tertinggi sebesar $92 \%$ pada jam 16.00 WIB dan yang terendah adalah 59\% pada jam $12.00 \mathrm{WIB}$, untuk kondisi luar kelembaban bangunan yang tertinggi pada Jam 16.00 WIB dengan besar kelembaban $95 \%$ dan terendah adalah $60 \%$ pada pukul 10.00 WIB. Untuk bulan Januari Kelembaban yang tertinggi adalah sebesar 75\% pada jam 08.00 WIB dan yang terendah $59 \%$ pada pukul 15.00 WIB. Sedangkan untuk kondisi ruang luar kelembaban rumah tertinggi adalah $71 \%$ jam 13.00 WIB, dan yang terendah $61 \%$ pada pukul 10.00 WIB. Maka dari data tersebut disimpulkan Betang TMII memiliki kelembaban didalam bangunan yang tidak nyaman pada saat sore dan pagi hari pada bulan November dan Januari. Sedangkan untuk keadaan kelembaban diluar bangunan Betang TMII juga memiliki kelembaban yang tidak nyaman baik keadaan pagi dan sore hari di bulan November dan Januari. Terlihat juga besar kecepatan angin yang masuk dengan nilai tertinggi sebesar $3 \mathrm{~m} / \mathrm{s}$ dengan rata-rata $0,8 \mathrm{~m} / \mathrm{s}$ pada bulan November, serta nilai tertinggi pada bulan januari sebesar $1 \mathrm{~m} / \mathrm{s}$ dengan rata-rata $0,3 \mathrm{~m} / \mathrm{s}$.
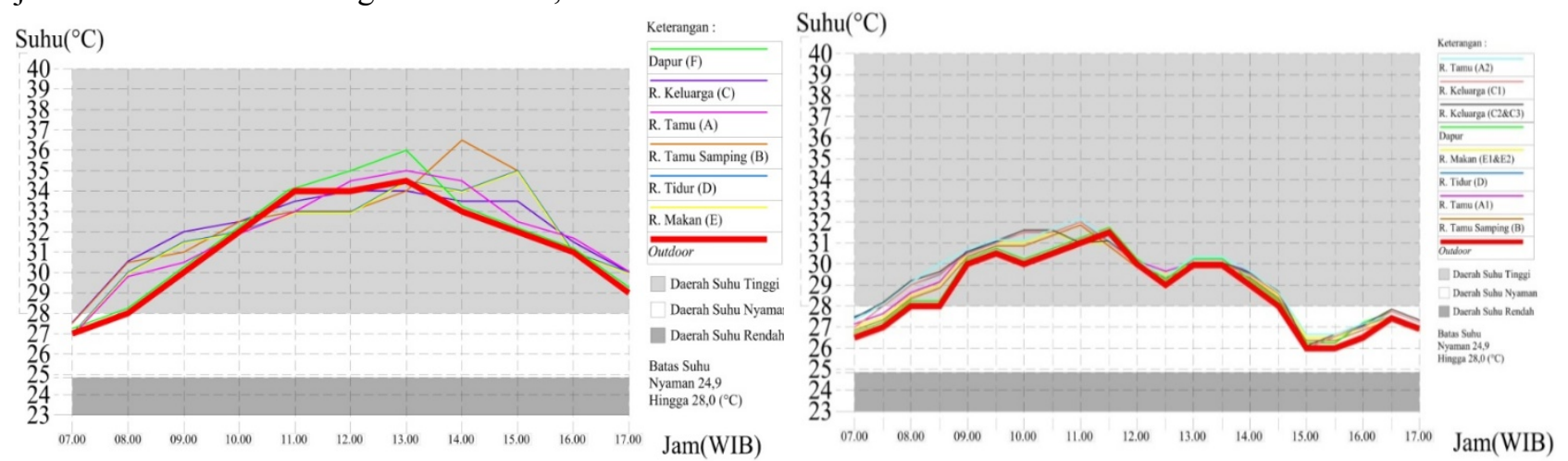

Gambar 9. Kurva suhu Huma Gantung / Betang Buntoi Oktober dan Januari

(Sumber: Observasi, 2019, 2020) 
Berdasarkan kurva disimpulkan bahwa pada Bulan Oktober memiliki rata-rata suhu dalam bangunan yang tertinggi sebesar $36,5^{\circ} \mathrm{C}$ dan suhu yang terendah dengan rata-rata $27^{\circ} \mathrm{C}$, untuk rata-rata keseluruhan suhu dalam sendiri sebesar $31,8^{\circ} \mathrm{C}$. Sedangkan untuk suhu luar memiliki nilai tertinggi sebesar $34,5^{\circ} \mathrm{C}$ dengan nilai terendah sebesar $27^{\circ} \mathrm{C}$, untuk rata-rata suhu luar yang terjadi memiliki nilai $31,3^{\circ} \mathrm{C}$. Pada Bulan Januari memiliki rata-rata suhu dalam bangunan yang tertinggi sebesar $32^{\circ} \mathrm{C}$ dan suhu yang terendah dengan rata-rata $26^{\circ} \mathrm{C}$, untuk rata-rata keseluruhan suhu dalam sendiri sebesar $29^{\circ} \mathrm{C}$. Sedangkan untuk suhu luar memiliki nilai tertinggi sebesar $31,5^{\circ} \mathrm{C}$ dengan nilai terendah sebesar $26^{\circ} \mathrm{C}$, untuk rata-rata suhu luar yang terjadi memiliki nilai $28,6^{\circ} \mathrm{C}$.
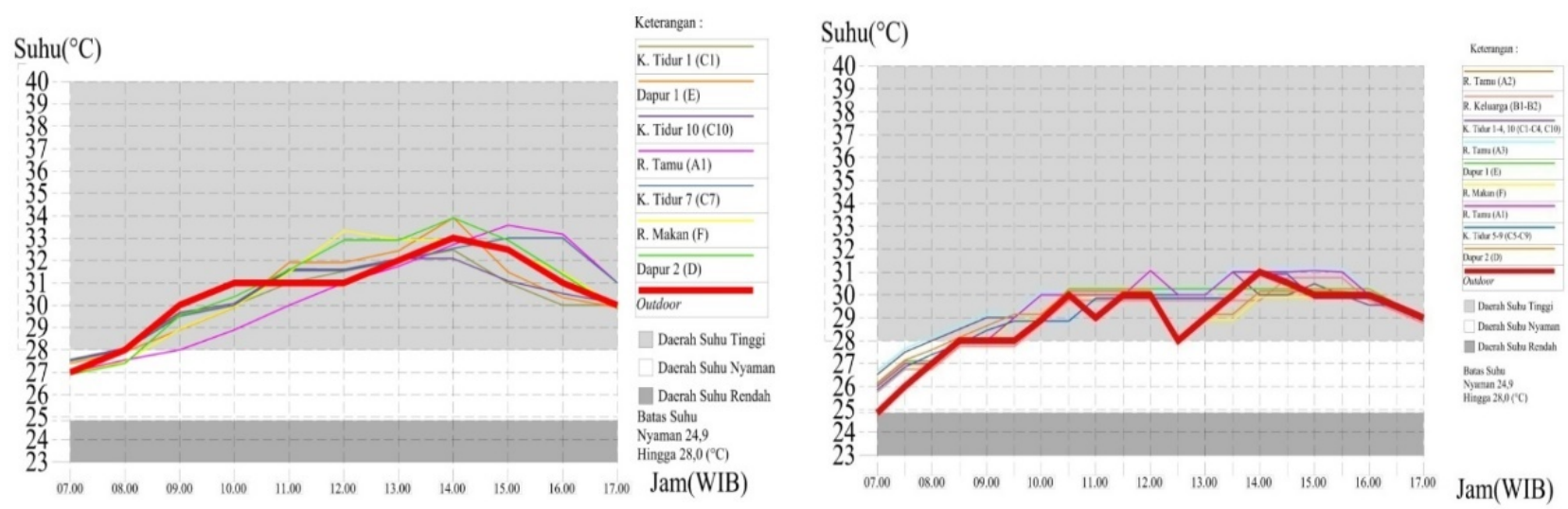

Gambar 10. Kurva suhu Betang Toyoi Oktober dan Januari (Sumber: Observasi, 2019, 2020)

Berdasarkan kurva disimpulkan bahwa pada Bulan Oktober memiliki rata-rata suhu dalam bangunan yang tertinggi sebesar $34^{\circ} \mathrm{C}$ dan suhu yang terendah dengan rata-rata $27^{\circ} \mathrm{C}$, untuk rata-rata keseluruhan suhu dalam sendiri sebesar $30,6^{\circ} \mathrm{C}$. Sedangkan untuk suhu luar memiliki nilai tertinggi sebesar $33^{\circ} \mathrm{C}$ dengan nilai terendah sebesar $27^{\circ} \mathrm{C}$, untuk rata-rata suhu luar yang terjadi memiliki nilai $30,5^{\circ} \mathrm{C}$. Pada Bulan Januari memiliki rata-rata suhu dalam bangunan yang tertinggi sebesar $31^{\circ} \mathrm{C}$ dan suhu yang terendah dengan rata-rata $25^{\circ} \mathrm{C}$, untuk rata-rata keseluruhan suhu dalam sendiri sebesar $28.9^{\circ} \mathrm{C}$. Sedangkan untuk suhu luar memiliki nilai tertinggi sebesar $31^{\circ} \mathrm{C}$ dengan nilai terendah sebesar $25^{\circ} \mathrm{C}$, untuk rata-rata suhu luar yang terjadi memiliki nilai $28,9^{\circ} \mathrm{C}$.
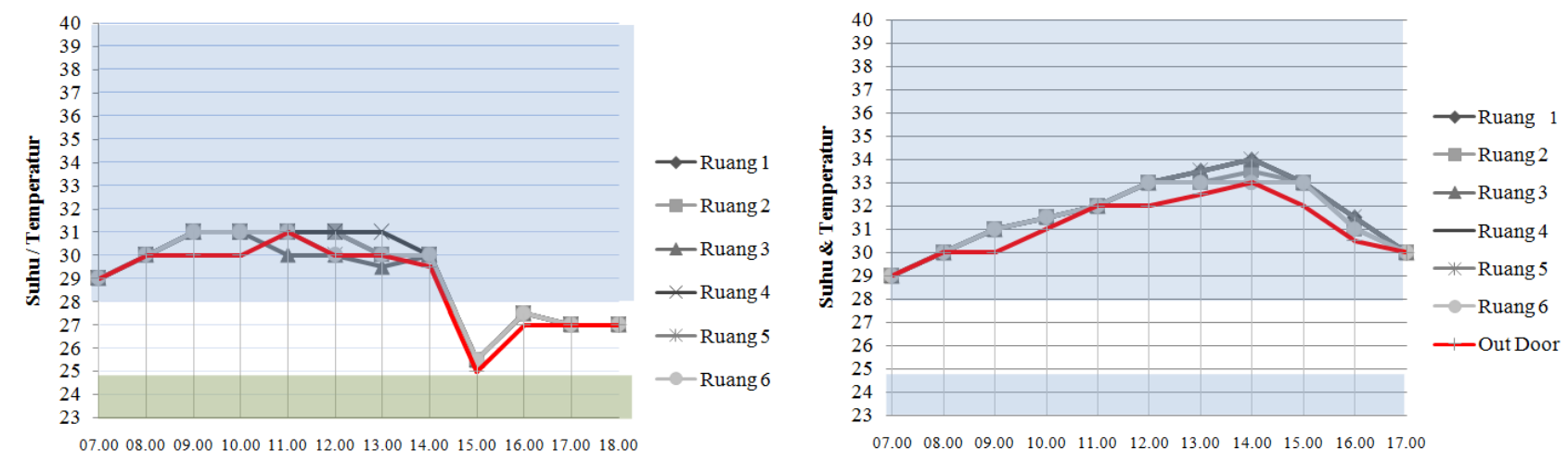

Gambar 11. Kurva suhu Bentang TMII November dan Januari

(Sumber: Observasi, 2019, 2020)

Berdasarkan kurva disimpulkan bahwa pada Bulan November memiliki rata-rata suhu dalam bangunan yang tertinggi sebesar $31^{\circ} \mathrm{C}$ dan suhu yang terendah dengan rata-rata $25,4^{\circ} \mathrm{C}$, untuk rata-rata keseluruhan suhu dalam sendiri sebesar $29,25^{\circ} \mathrm{C}$. Sedangkan untuk suhu luar memiliki nilai tertinggi sebesar $31^{\circ} \mathrm{C}$ dengan nilai terendah sebesar $25^{\circ} \mathrm{C}$, untuk rata-rata suhu luar yang terjadi memiliki nilai $28,9^{\circ} \mathrm{C}$. Pada Bulan Januari memiliki rata-rata suhu dalam bangunan yang tertinggi sebesar $33,6^{\circ} \mathrm{C}$ dan suhu yang terendah dengan rata-rata $29^{\circ} \mathrm{C}$, untuk rata-rata keseluruhan suhu dalam sendiri sebesar $31,5^{\circ} \mathrm{C}$. Sedangkan untuk suhu luar memiliki nilai tertinggi sebesar $33^{\circ} \mathrm{C}$ dengan nilai terendah sebesar $25^{\circ} \mathrm{C}$, untuk rata-rata suhu luar yang terjadi memiliki nilai $31^{\circ} \mathrm{C}$. 


\section{Kesimpulan}

Akan dilakukan perbandingan antara Betang Toyoi dengan Bentang Buntoi, kemudian dilanjutkan perbandingan antara Betang Toyoi dengan Betang TMII, serta perbandingan antara Betang Buntoi dengan Betang TMII. Pada perbandingan antara Betang Toyoi dengan Bentang Buntoi yaitu rata-rata suhu ruang dalam pada Betang Buntoi sebesar $31.8^{\circ} \mathrm{C}$ lebih besar dari pada Betang Toyoi yang hanya mencapai $30.6^{\circ} \mathrm{C}$ pada musim kemarau, selisih temperatur yang terjadi mencapai 1,2 poin. Sedangkan pada ruang luar suhu tertinggi Betang Buntoi mencapai $31.3^{\circ} \mathrm{C}$ lebih besar dari pada Betang Toyoi yang hanya mencapai $30.5^{\circ} \mathrm{C}$ pada musim kemarau, selisih temperatur yang terjadi mencapai 0,7 poin. Suhu luar bangunan memberikan pengaruh yang cukup besar terhadap tingkat suhu di dalam bangunan, pada saat musim hujan ruang luar pada Betang Toyoi memiliki suhu yang lebih tinggi dibandingkan dengan Betang Buntoi, tetapi tetap suhu ruang dalam Betang Toyoi lebih rendah di bandingkan dengan Betang Buntoi.

Perbandingan antara Betang Toyoi dengan Bentang TMII yaitu pada Betang Toyoi saat musim kemarau memiliki suhu ruang dalam yang lebih tinggi dari pada betang di TMII pada saat bulan November, Berbeda pada saat musim hujan Betang Toyoi memiliki suhu ruang dalam yang lebih rendah dari pada Betang di TMII. Berdasarkan hal tersebut maka dibuat pernyataan bahwa Rumah Betang Toyoi lebih mampu mengatasi keadaan suhu ruang luar yang tinggi, di bandingkan dengan Rumah TMII yang memiliki keadaan suhu ruang luar yang tinggi serta suhu di dalam ruangan yang juga tinggi. Disimpulkan juga bahwa Rumah Betang di TMII tidak dapat mengatasi kondisi ruang luar pada bangunannya, hal ini terlihat dari semakin sering terjadinya persamaan suhu ruangan di dalam maupun diluar bangunan baik pada saat hujan maupun kemarau.

Perbandingan antara Betang Buntoi / Huma Gantung dengan Bentang TMII yaitu pada Betang Buntoi saat musim kemarau memiliki suhu ruang dalam yang lebih tinggi dari pada Betang TMII pada saat bulan November. Saat musim hujan Betang Buntoi memiliki suhu ruang dalam yang lebih rendah dari pada Betang TMII. Suhu luar bangunan memberikan pengaruh yang cukup besar terhadap tingkat suhu di dalam bangunan, pada saat musim hujan ruang luar pada Betang TMII memiliki suhu yang lebih tinggi dibandingkan dengan Betang Buntoi. Berdasarkan hal tersebut maka dibuat pernyataan bahwa Rumah Betang Buntoi dan TMII sama-sama memiliki perbedaan suhu ruang dalam pada saat musim kemarau dan hujan, hal ini juga terjadi pada ruang luar bangunan yang juga mengalami perbedaan suhu baik pada saat musim kemarau maupun saat musim hujan.

\section{Ucapan Terima Kasih}

Penelitian ini didanai secara mandiri, tetapi beberapa instansi terkait sangat berkontribusi dalam penyelesaian penelitian ini, yang pertama kami ucapkan terima kasih kepada Universitas Trisakti yang memberi ijin dalam melakukan penelitian ini, termasuk arahan dan gagasannya, serta Instansi Dinas Kebudayaan dan Pariwisata Provinsi Kalimantan Tengah atas dukungan serta sarannya, juga semua pihak yang secara langsung dan tidak langsung memberikan dukungan moril dan materil dalam penyelesaian penelitian ini kami mengucapkan terima kasih banyak.

\section{Daftar Pustaka}

Alfata, M. N. F., Nugroho, A. M., \& Ekasiwi, S. N. (2014). Kenyamanan Termal pada Ruang Iklim di Dua Daerah Dengan Karakteristik Iklim yang Berbeda, Studi Kasus : Malang dan Surabaya. Jurnal Permukiman, 9, 28-40. http://jurnalpermukiman.pu.go.id/index.php/JP/article/view/69

ASHRAE. (2017). 2017, ASHRAE fundamental handbook SI (Mark S. Owen (ed.)). ASHRAE. https://www.ashrae.org/technical-resources/ashrae-handbook/description-2017-ashrae-handbook-fundamentals

Hamidah, N., \& Garib, T. W. (2014). Studi Arsitektur Rumah Betang Kalimantan Tengah. Jurnal Arsitektur Melayu Dan Lingkungan, 1(2).

Karyono, T. H. (2010). Kenyamanan Termal dalam Arsitektur Tropis. Arsitektur Dan Kota Tropis Dunia Ketiga: Suatu Bahasan Tentang Indonesia. https://www.researchgate.net/publication/305189048_KENYAMANAN_TERMAL_DALAM_ARSITEKTUR_T ROPIS

Karyono, T. H. (2016). Arsitektur tropis: bentuk, teknologi, kenyamanan \& penggunaan energi. Erlangga. https://books.google.co.id/books?id=b8\%5C_TAQAACAAJ

Lippsmeier, G. (1994). Bangunan Tropis (Ed.ke-2). Erlangga.

Putri, A. M. (2017). Konsep Lamin dalam Bangunan Modern dengan Pendekatan Vernakular: Studi Kasus Gedung Keuskupan Agung Samarinda. In Seminar Nasional Seni dan Desain 2017 (pp. 124-130).

Samsoedin, I., Wijaya, A., \& Sukiman, H. (2010). Konsep Tata Ruang dan Pengelolaan Lahan pada Masyarakat Dayak Kenyah di Kalimantan Timur. Jurnal Analisis Kebijakan Kehutanan.

Santoso, E. I. (2012). Kenyamanan Termal Indoor Pada Bangunan Di Daerah Beriklim Tropis Lembab. Indonesian Green Technology Journal, 1(1), 13-19. 
Singarimbun, M. (1991). Beberapa Aspek Kehidupan Masyarakat Dayak. Humaniora, 3.

SNI 03-6572-2001. (2001). Tata cara perancangan sistem ventilasi dan pengkondisian udara pada bangunan gedung. DAMKAR Kabupaten Sukabumi.

Sugiyono. (2019). Metode Penelitian Kuantitatif, Kualitatif, dan R\&D (2nd ed.). Alfabeta.

Swasti, T. E. (2016). Pengaruh Kerapatan Bangunan pada Karakteristik Termal Rumah Tinggal Kampung Naga terhadap Kenyamanan Penghuni. Vitruvian: Jurnal Arsitektur, Bangunan, Dan Lingkungan, 5(2).

Toding, J. B., Kindangen, P. J. I., \& Sangkertadi, P. (2015). Kenyamanan Termal Rumah Tepi Sungai, Studi Kasus Rumah Tepi Sungai Kahayan, Palangka Raya, Indonesia. Radial, 3(2), 102-111.

Usop, T. B. (2015). Pengaruh Bentukan Arsitektur Terhadap Kenyamanan Thermal pada Rumah Betang di Kalimantan Tengah. Jurnal Perspektif Arsitektur, 10, 131. https://e-journal.upr.ac.id/index.php/JTA/article/view/923/747

Usop, T. B. (2019). Pelestarian Arsitektur Tradisional Dayak pada Pengenalan Ragam Bentuk Konstruksi dan Teknologi Tradisional Dayak di Kalimantan Tengah. Jurnal Perspektif Arsitektur, 9, 45. https://www.researchgate.net/publication/334731665_PELESTARIAN_ARSITEKTUR_TRADISIONAL_DAYA K_PADA_PENGENALAN_RAGAM_BENTUK_KONSTRUKSI_DAN_TEKNOLOGI_TRADISIONAL_DAY AK DI KALIMANTAN TENGAH

Wahyudi, E. (2018). Pengaruh Bentuk Bukaan Atap Bangunan terhadap Tingkat Kenyamanan Termal pada Rumah Panjang Suku Dayak Brusu, Kecamatan Sekatak, Kalimantan Utara. Borneo Engineering, 2(2), 94-104.

Cuaca.mirbig.net. Kondisi Cuaca, 2019, https://cuaca.mirbig.net/id/ID/13/1639304_Kualakapuas. Diakses pada 19 Oktober 2019.

id.wikipedia.org. Kabupaten Kapuas, 2019, https://id.wikipedia.org/wiki/Kabupaten Kapuas. Diakses pada 30 Oktober 2019 